\title{
Impact of nutrition on human fertility
}

\author{
Vesna Otašević ${ }^{1}$, Aleksandra Korać2, \\ Ana Stančić ${ }^{\prime}$, Aleksandra Janković ${ }^{\prime}$, \\ Bato Korać 1,2 \\ ${ }^{1}$ University of Belgrade, Institute for \\ Biological Research "Siniša Stanković", \\ Bulevar despota Stefana 142, Belgrade, \\ Serbia; \\ 2 University of Belgrade, Faculty of Biology, \\ Belgrade, Serbia. \\ Address of correspondence: \\ Professor Bato Korać, PhD \\ University of Belgrade, Institute for \\ Biological Research „Siniša Stanković”, \\ Department of Physiology, Bulevar despota \\ Stefana 142, 11060 Belgrade, Serbia \\ Tel.: (381-11)-2078-307 \\ Fax: (381-11)-2761-433 \\ e-mail: koracb@ibiss.bg.ac.rs
}

\begin{abstract}
Infertility is one of the most serious medical issues that is dramatically rising worldwide. Extensive research dedicated to this problem clearly shows that infertility is a disease of modern society and that a nutrition has a great influence on the development of sterility. Thus, the impact of specific nutritional factors, i.e. diet pattern on both male and female fertility is included in this review. It is encouraging that modification of nutritional habits can help couples to conceive spontaneously, or increase their chances of conception with in vitro fertilization (IVF) treatment.
\end{abstract}

Key words: Infertility, nutrition, obesity, fat, carbohydrates, proteins, micronutrients

\section{INTRODUCTION}

Infertility is one of the most serious medical issues that has dramatically increased in our country and worldwide, especially in a recent years [1]. Sterility is almost identically represented in both men and women (from $30 \%$ to $40 \%$ ) and is caused by a various number of factors $[2,3]$. Certain factors that cause infertility can only be successfully overcome by using assisted reproduction methods and most often in vitro fertilization (IVF) is the only possible path to parenting. The development of medicine in the field of infertility treatment and in artificial reproductive technologies (ART) allows $80 \%$ of couples to achieve their goal and become parents. However, despite the progress in reproductive medicine, infertility progresses too. Thus, a crucial direction in biomedicine today is the development of new approaches for infertility treatment. Extensive research dedicated to this problem clearly shows that sterility is a disease of modern society and that lifestyle has a substantial impact on the development of sterility. In particular, it has been shown that bad nutrition, i.e. specific nutritional factors significantly influence human (in)fertility [4]. What is encouraging when we talk about nutrition is the fact that nutritional factors are easily interchangeable and that simple modification of diet pattern can have a huge impact on (in)fertility.

Healthy dietary pattern among both men and women of reproductive age includes foods which are dense in specific nutrients needed for hormonal func- tion, production and balance, fetal development, egg health, sperm health, blood health and much more. Although the meaning of unhealthy dietary pattern to some extent varies across the studies, it have remarkable overlaps in diets rich in calories [5], trans-fatty acids (TFAs), saturated fats [6] or cholesterol [7] that have been associated with testicular disruption, impairments in spermatogenesis, menstrual dysfunction, anovulation, infertility, miscarriage, and pregnancy complications $[8,9]$. On the other hand, diet rich in fiber, whole grains, fruits, vegetables, fish and olive oil, folate and lycopene; the use of vegetable rather than animal proteins, full-fat dairy products, food with reduced glycemic index and unsaturated fats have been shown to improve fertility in women and quality of semen in men, ART outcomes and chance of pregnancy [10-12] (Scheme 1).

How diet is important to fertility best exemplifies the Harvard study [13] in which 18555 married women without a history of infertility were followed up as they attempted pregnancy or became pregnant during an 8 year period. Results showed that consuming $5 \%$ of total energy intake as vegetable protein rather than as animal protein was associated with a more than $50 \%$ lower risk of ovulatory infertility. In addition, women with higher intake of mono-unsaturated over trans-fat ratio, vegetable over animal protein, high-fat over lowfat diary, a decreased glycemic load, and an increased intake of multivitamins had lower rates of ovulation 
Scheme 1. Impact of nutritional factors on human fertility

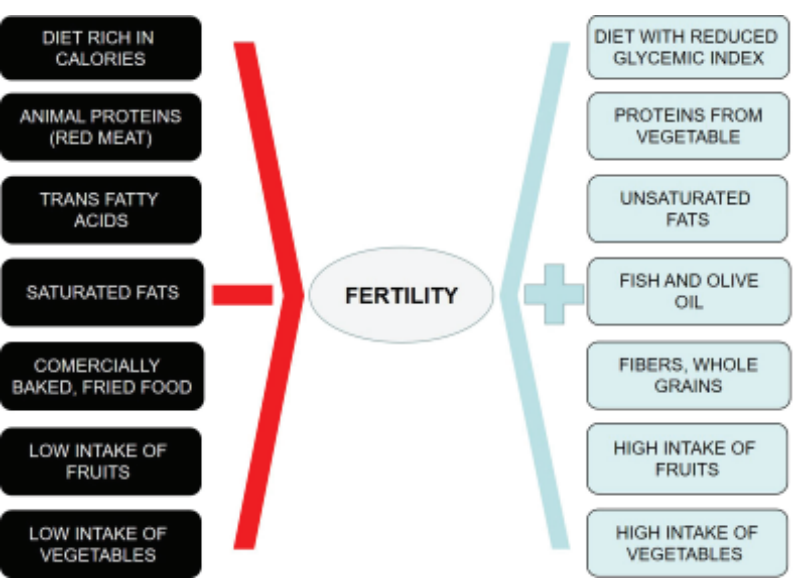

disorders [13]. Diet consisting of the aforementioned food groups is Mediterranean diet which is clearly shown to be beneficial on achieving clinical pregnancy and live birth among non-obese women, but specifically those below the age of 35 [14]. The same holds true for men. Namely, it has been shown that healthy dietary pattern, such as Mediterranean type of diet has been strongly associated with better semen quality parameters worldwide [15-17]. In addition, the healthy dietary pattern has been shown to be associated with decrease in sperm DNA fragmentation index [15].

Generally, infertility caused by nutritional factors is associated with changes in the synthesis and activity of hormones, or quality of gametes. Estrogen, the main sexual hormone in women is produced in two places in the body, ovaries and adipose tissue. High or low levels of body fat affect the synthesis of estrogen. These changes in the production of estrogen may cause permanent or temporary infertility, since the disorder of menstrual cycle or ovulation. The general rule is that people who have a body mass index (BMI) below 20 or over 30 are out of weight range for achievement of optimal fertility. Underweight, namely, weighting 10-15\% less than an ideal body weight can result in a disturbed menstrual cycle [12]. On the other hand, a slight increase in body weight in women with extremely low percentage of body fat can improve fertility. In obese women insulin resistance adversely affects fertility [18]. Women with a BMI over 30 have bad endometrial receptivity, and thus a significantly higher percentage of spontaneous abortions (13.6\% compared to $10.7 \%$ in women with normal $\mathrm{BMI}$ ) and lower rates of pregnancy $(38.3 \%$ vs $45.5 \%)[19,20]$. Obesity is common in women of reproductive age, with $38.3 \%$ of women over 20 years of age classified as obese [8]. In addition, assisted reproduction is less effective in overweight and obese women, with lower pregnancy and live birth rates, and increased incidence of pregnancy loss [8].

Obesity affects the fertility of men too. An increase in BMI of only 3 units significantly reduces sperm parameters [21], and increases the number of mutations in the DNA of spermatozoa [22]. Also, the lack of body weight or excessive accumulation of fat in the abdominal area is associated with reduced synthesis of testosterone and consequently poor sperm quality [23]. Many factors may explain the relationship between overweight and poor sperm parameters, which includes alterations in hormones, such as decreased testosterone, increased estradiol, and elevated endorphins that can impact sperm production; hyperinsulinemia, which may mediate a decrease in sex hormone-binding globulin in obese men; a rise in scrotal temperature caused by fat tissue accumulation; and an increased accumulation of toxic substances in fatty tissue [24].

Luckily, negative effects of obesity on the fertility of both men and women may be reversible. Numerous studies have shown that normalization of body fat influences the levels of reproductive hormones and consequently improved fertility. The best way to maintain/ achieve an ideal body weight and good reproductive performance is to eat a healthy, balanced diet. Still, there are specific nutrients and food categories that are particularly important for reproductive function bot in women and men. First, macronutrients are required fats, carbohydrates and protein. Then there are essential vitamins and minerals (micronutrients), cholesterol and fiber. Importance of this nutrients on human fertility are summarized below.

\section{MACRONUTRIENTS}

\section{Carbohydrates}

Dietary carbohydrates impact fertility by influencing glucose homeostasis and insulin sensitivity, which in turn affects ovarian androgen production and ovarian function [25]. Data from the large prospective cohort of healthy women in the Nurse's Healthy Study II (NHSII), revealed that both total carbohydrate consumption and glycemic load were associated with higher risks of ovulatory infertility [26]. Accordingly, it has been shown that reduction in dietary carbohydrates among women with polycystic ovary syndrome improved insulin sensitivity and enhance ovulatory function [27]. In the line with this are results showing that constituents of whole grains, which have a beneficial effects on glucose metabolism, increase fertilizing potential by increasing insulin sensitivity [28]. Also, women who had higher preconception intake of whole grains is associated with higher rate of live birth [29]. High dietary load of carbohydrates negatively impact men fertility too. A recent study associated high intakes of refined carbohydrates and the ensuing high blood glucose levels with a decreased sperm count in young men [30]. According to systematic review that covers two decades, as carbohydrate intake and dietary glycemic load increase sperm concentration and semen quality decreased, unrelated to the male years [31]. 


\section{Dietary fats}

Fatty acids (saturated, SFA; monosaturated, MUFA and polyunsaturated, PUFA) are very important for numerous reproductive functions in humans. In men, composition of sperm cell membrane is of utmost importance for proper sperm function, i.e. crucial sperm fertilizing processes - capacitation, acrosome reaction, sperm-oocyte fusion [1]. As sperm matures, the amount of PUFA (especially docosahexaenoic acid, DHA) increases. Consumption of food rich in these fatty acids modifies composition of sperm membrane and consequently, semen quality [32]. Higher intake of omega-3 PUFAs has been related to increased population of morphologically normal sperm [32], and increased sperm count [30]. Walnuts contain large concentration of omega- 3 fatty acids, and supplementation of young men consuming Western diet with $75 \mathrm{~g} / \mathrm{d}$ for 12 weeks significantly improved all functional parameters of sperm, compared to control subjects [32]. In female, fatty acids are used as energy substrates during oocyte maturation and early embryo development [33]. As a precursor for prostaglandins and steroid hormones, they are also vital for implantation and pregnancy maintenance [33]. Accordingly, intake of DHA has been shown to be associated with increase in total level of estradiol and lower risk of anovulation [34]. On the other hand trans fatty acids have deleterious effects on reproductive functions both in men and women. These fatty acids are primarily found in commercially baked and fried food, and after consumption they accumulate in the testis, leading to defective spermatogenesis, poor semen quality and subfertility $[32,34]$. Trans fat intake was associated with hormonal disables [35], increased ovulatory infertility [12] and reduced fecundability [33].

\section{Proteins}

Proteins are micro nutrients that are vital both for conception and pregnancy. They are responsible for building and repairing cell, producing hormones and a healthy reproductive functions. However, proteins from different foods are different in their effects on reproductive functions in both sexes. The main sources of protein in human nutrition are milk (dairy) and meat. Generally, literature on the relationship between dairy product intake and human fertility is inconclusive. While one study reported few associations between preconception dairy intake and fertility in two populations of reproductive-aged women [33], NHS II reported no associations between total intake of dairy products and risk of infertility [36]. In terms of effects of fat percent in dairy products, it has been reported association of full-fat dairy products intake with a lower risk of ovulatory infertility and association of low-fat dairy products and a high ovulatory infertility risk [36]. Similar inconsistence was observed in male population. Here some studies suggested dairy as a possible risk for poorer semen parameters while other did not support this standpoint [32]. While few stud- ies reported that intake of full-fat dairy products was adversely related to normal sperm morphology and motility, cross-sectional study among fertility patients in the Netherlands reported no correlation between dairy intake and semen quality [15]. Studies about relation between meat intake and semen quality generally suggest that red meat have an adverse effects. Two cross-sectional studies reveled lower sperm concentration and motility and morphology in men who consumed higher amounts of processed meat [30,32]. In women, results from an infertility cohort study showed that blastocyst formation during embryo development was affected negatively by consumption of red meat and positively by consumption of fish [33]. Also, ovulation was negatively affected by increased meat intake among NHS-II participants [12].

\section{MICRONUTRIENTS}

\section{Folic acid}

In addition to its beneficial role in preventing neural tube defects in infants, folic acid is important for normal reproductive functions both in women and men $[32,33]$. Namely, it has been shown that subfertile women who took a multivitamin containing $400 \mu \mathrm{g}$ of folic acid for three months had a $26 \%$ of pregnancy comparing to women in placebo group, who had $10 \%$ of pregnancy [37]. Explanation for this relays in a fact that multivitamin users had approximately one third lower risk for developing ovulatory infertility compared to nonusers. Similarly, Biocycle study reveal that folate intake decreased frequency of anovulation of young healthy women, while Danish study reported shorter time to pregnancy in pregnancy planners [33]. In addition, favorable effect of folic acid supplementation on ART outcomes has been shown among subfertile women [37]. In men, folic acid intake improved sperm count, as well as proportion of motile spermatozoa $[32,38]$. Also, seminal plasma folate emerged as very important for sperm DNA integrity and sperm aneuploidy [39]. Nevertheless, dose-response benefit of folate seems to be beyond the recommended for the prevention of neural tube defects and testing oriented to dose determination still running. However, current evidence based on such beneficial data, strongly recommend folic acid supplementation before and during pregnancy.

\section{Vitamins A, C, D, E}

Data concerning effects of vitamins on fertility have some limitations particularly in studies on females, where multivitamins rather than monosubstances, were tested. Thus, the effect cannot always be absolutely attributed to one substance. Anyway, positive effects of these substances on human fertility deserves further attention. Vitamin C seems to be very important for sperm functioning. Namely, it was shown that administration of 200 and $1000 \mathrm{mg}$ of vitamin C daily 
significantly improved sperm quality [39], as well as administration of combination of vitamin C and $E$ [39]. Also, a significantly higher seminal vitamin $C$ level in fertile vs. infertile individuals, as well as a correlation between seminal vitamin $C$ and the percentage of sperm with normal morphology was shown by Colagar and Marzony [40]. In women with luteal phase defects, daily substitution of $750 \mathrm{mg}$ of vitamin C for a six months significantly increased level of progesterone and estrogen, as well as pregnancy rate [39]. A several studies revealed an improvement of various sperm parameters, as well as a higher pregnancy rate after substitution with 300-600 mg per day of vitamin E [39]. Also, serum concentrations of retinol and a-tocopherol in men with normal sperm parameters were significantly higher than in those with oligozoospermia and asthenozoospermia [41]. Prospective studies of vitamin A and human fertility tested mixed substances only. Data from these studies revealed an increased sperm count after therapy with a mix of antioxidants containing $0.06 \mathrm{IU} /$ kg vitamin A [39] and improved conception rate, progesterone level and rate of mid luteal days in women supplemented with multivitamin containing 3600 IU of vitamin A [39]. Despite the shown positive correlation between vitamin $D$ and sperm motility and morphology [32], as well as on various reproductive processes in women, these data are based on association and in vitro studies and should therefore be interpreted with caution.

\section{Selenium, Zinc, lodine, Coenzyme Q10}

Both selenium and iodine are important for synthesis of thyroid hormones. Considering that thyroid dysfunction lead to impaired spermatogenesis it is clear that both iodine and selenium deficiency influence male infertility. Accordingly, it has been shown that combination preparations containing $100-200 \mu \mathrm{g}$ of these elements achieved beneficial effects on several sperm parameters $[42,43]$. In women, patients with unexplained infertility had significantly decreased follicular selenium concentrations compared with those with a male-related cause of infertility [44]. Apart of its role in protein synthesis, zinc is very important for human reproduction. Sperm motility, as well as sperm count and morphology significantly increased after substitution with $400 \mathrm{mg}$ of zinc sulfate alone [45] or along with 5 mg of folic acid [46]. Cross-sectional studies showed a direct link between the coenzyme Q10 concentrations in the seminal fluid and sperm count and motility [47], while a prospective study showed an improvement in sperm motility after 6 months of therapy with $200 \mathrm{mg}$ of coenzyme Q10 [48]. Studies performed on females have a limitation in the sense that multivitamins containing $\mathrm{Zn}$ have been used instead of monosubstance and due to that, beneficial effects of these treatments on reproductive outcome of female, cannot be attributed to one substance ( $\mathrm{Zn}$ in this case).

\section{CONCLUSION}

Finally, taking all this into account it can be concluded that modification of diet pattern may have huge impact on (in)fertility. Precisely, balanced healthy diet of each individual before and during conception attempts can be vital for improving fertility and achieving significant positive impact on reproductive health of couples. Also, apart from nutritional modifications, supplements can support the quality of gametes and help to treat infertility. Thus, given the beneficial effects of a healthy diet on reproductive outcome, there is an urgent need for integration of nutritional counseling into infertility treatments.

We do hope that this approach, which involves change in bad nutritional habits, especially in couples who are undergoing IVF, could enhance their reproductive performance and efficiency of treatment, perhaps even reduce the need for invasive and costly high-technological fertilization procedures.

\section{Acknowledgment}

This work was supported by the Ministry of Education, Science and Technological Development of the Republic of Serbia, Grant no. 173054.

\section{REFERENCES}

1. Buzadžić $B$, Vučetić $M$, Janković $A$, Stančić $A$, Korać $A$, Korać $B$ et al. New insights into male (in)fertility: the importance of NO. Br J Pharmacol 2015; 172(6):1455-67.

2. Otašević $V$, Korać $A$, Vučetić $M$, Macanović $B$, Garalejic E, Ivanović-Burmazović I et al. Is manganese (II) pentaazamacrocyclic superoxide dismutase mimic beneficial for human sperm mitochondria function and motility? Antioxid Redox Signal 2013; 18(2):170-8.

3. Macanović $B$, Vučetić $M$, Janković $A$, Stančić $A$, Buzadžić $B$, Garalejić E et al. Correlation between sperm parameters and protein expression of antioxidative defense enzymes in seminal plasma: a pilot study. Dis Markers 2015; 436236.

4. Otasević V, Wagner D, Garalejić E. Effects of nutrition on IVF success rate: How diet and lifestyle affect fertility? Book of abstracts " $13^{\text {th }}$ Congress of nutrtition: Food and Nutrtition - A Roadmap to Better Health", Belgrade 2016; 103-4.

5. Rato L, Alves MG, Gavaco JE, Oliveira PF. High-energy diets: a threat for male infertility? Obes Rev 2014; 15(12):996-1007.

6. Ng SF, Lin RC, Laybutt DR, Barres R, Owens JA, Morris MJ. Chronic high-fat diet in fathers programs $\beta$-cell dysfunction in female rat offspring. Nature 2010; 467(7318):963-6.

7. Morgan DH, Ghribi O, Hui L, Geiger JD, Chen X. Cholesterol-enriched diet disrupts the blood-testis barrier in rabbits. Am J Physiol Endocrinol Metab 2014; 307(12):E1125-30.

8. Ogden CL, Carroll MD, Fryar CD, Flegal KM. Prevalence of Obesity Among Adults and Youth: United States, 20112014. NCHS Data Brief 2015; 219:1-8.

9. Bellver J, Ayllón Y, Ferrando M, Melo M, Goyri E, Pellicer $A$ et al. Female obesity impairs in vitro fertilization out- 
come without affecting embryo quality. Fertil Steril 2010; 93(2):447-54.

10. Gaskins AJ, Chavarro JE. Diet and fertility: a review. Am J Obstet Gynecol 2018; 218(4):379-89.

11. Hohos NM, Skaznik-Wikiel ME. High-Fat Diet and Female Fertility. Endocrinology 2017; 158(8):2407-19.

12. Chavarro JE, Rich-Edwards JW, Rosner BA, Willett WC. Dietary fatty acid intakes and the risk of ovulatory infertility. Am J Clin Nutr 2007; 85(1):231-7.

13. Chavarro JE, Rich-Edwards JW, Rosner BA, Willett WC. Protein intake and ovulatory infertility. Am J Obstet Gynecol 2008; 198(2):210. e1-7.

14. Karayiannis D, Kontogianni MD, Mendorou C, Mastrominas $M$, Yiannakouris $N$. Adherence to the Mediterranean diet and IVF success rate among non-obese women attempting fertility. Hum Reprod 2018; 33(3):494-502.

15. Vujkovic M, de Vries JH, Dohle GR, Bonsel GJ, Lindemans $J$, Macklon NS et al. Associations between dietary patterns and semen quality in men undergoing IVF/ICSI treatment. Hum Reprod 2009; 24(6):1304-12.

16. Liu CY, Chou YC, Chao JC, Hsu CY, Cha TL, Tsao CW. The Association between Dietary Patterns and Semen Quality in a General Asian Population of 7282 Males. PLoS One 2015; 10(7):e0134224.

17. Salas-Huetos A, Bulló M, Salas-Salvadó J. Dietary patterns, foods and nutrients in male fertility parameters and fecundability: a systematic review of observational studies. Hum Reprod Update 2017; 23(4):371-89.

18. Kirchengast S, Gruber D, Sator M, Hartmann B, Knogler W, Huber J. Menopause-associated differences in female fat patterning estimated by dual-energy X-ray absorptiometry. Ann Hum Biol 1997; 24(1):45-54.

19. Boots C, Stephenson MD. Does obesity increase the risk of miscarriage in spontaneous conception: A systematic review. Semin Reprod Med 2011; 29(6):507-13.

20. Bellver J, Melo MA, Bosch E, Serra V, Remohi J, Pellicer A. Obesity and poor reproductive outcome: The potential role of the endometrium. Fertil Steril 2007; 88(2):446-51.

21. Sallmen M, Sandler DP, Hoppin JA, Blair A, Baird DD. Reduced fertility among overweight and obese men. Epidemiology 2006; 17(5):520-3.

22. Mendiola J, Torres-Cantero AM, Vioque J, Moreno-Grau JM, Ten J, Roca M, Moreno-Grau S et al. A low intake of antioxidant nutrients is associated with poor semen quality in patients attending fertility clinics. Fertil Steril 2010; 93(4):1128.

23. Makhsida N, Shah J, Yan G, Fisch H, Shabsigh R. Hypogonadism and metabolic syndrome: implications for testosterone therapy. J Urol 2005; 174(3):827-34.

24. Sermondade N, Faure C, Fezeu L, Shayeb AG, Bonde JP, Jensen TK et al. BMI in relation to sperm count: an updated systematic review and collaborative meta-analysis. Hum Reprod Update 2013; 19(3):221-31.

25. Blaak EE. Carbohydrate quantity and quality and cardio-metabolic risk. Curr Opin Clin Nutr Metab Care 2016; 19(4):289-93.

26. Chavarro JE, Rich-Edwards JW, Rosner BA, Willett WC. A prospective study of dietary carbohydrate quantity and quality in relation to risk of ovulatory infertility. Eur J Clin Nutr 2009; 63(1):78-86.

27. Douglas CC, Gower BA, Darnell BE, Ovalle F, Oster RA, Azziz R. Role of diet in the treatment of polycystic ovary syndrome. Fertil Steril 2006; 85(3):679-88.
28. Agarwal A, Aponte-Mellado A, Premkumar BJ, Shaman A, Gupta $S$. The effects of oxidative stress on female reproduction: a review. Reprod Biol Endocrinol 2012; 10:49.

29. Gaskins AJ, Chiu YH, Williams PL, Keller MG, Toth TL, Hauser R et al. EARTH Study Team. Maternal whole grain intake and outcomes of in vitro fertilization. Fertil Steril 2016; 105(6):1503-10.

30. Afeiche MC, Williams PL, Gaskins AJ, Mendiola J, Jørgensen N, Swan SH et al. Meat intake and reproductive parameters among young men. Epidemiology 2014; 25(3):323-30.

31. Giahi L, Mohammadmoradi S, Javidan A, Sadeghi MR. Nutritional modifications in male infertility: a systematic review covering 2 decades. Nutr Rev 2016; 74(2):118-30.

32. Nassan FL, Chavarro JE, Tanrikut C. Diet and men's fertility: does diet affect sperm quality? Fertil Steril 2018; 110(4):570-7.

33. Chiu YH, Chavarro JE, Souter I. Diet and female fertility: doctor, what should I eat? Fertil Steril 2018; 110(4):560-9.

34. Chavarro JE, Mínguez-Alarcón L, Mendiola J, Cutillas-Tolín A, López-Espín JJ, Torres-Cantero AM. Trans fatty acid intake is inversely related to total sperm count in young healthy men. Hum Reprod 2014; 29(3):429-40.

35. Mumford SL, Chavarro JE, Zhang C, Perkins NJ, Sjaarda LA, Pollack AZ et al. Dietary fat intake and reproductive hormone concentrations and ovulation in regularly menstruating women. Am J Clin Nutr 2016; 103(3):868-77.

36. Chavarro JE, Rich-Edwards JW, Rosner BA, Willett WC. A prospective study of dairy foods intake and ovulatory infertility. Hum Reprod 2007; 22(5):1340-7.

37. Westphal LM, Polan ML, Trant AS. Double-blind, placebo-controlled study of Fertilityblend: a nutritional supplement for improving fertility in women. Clin Exp Obstet Gynecol 2006; 33(4):205-8.

38. Chavarro JE, Schlaff WD. Introduction: Impact of nutrition on reproduction: an overview. Fertil Steril 2018; 110(4):557-9.

39. Buhling KJ, Laakmann E. The effect of micronutrient supplements on male fertility. Curr Opin Obstet Gynecol 2014; 26(3):199-209.

40. Colagar AH, Marzony ET. Ascorbic Acid in human seminal plasma: determination and its relationship to sperm quality. J Clin Biochem Nutr 2009; 45(2):144-9.

41. Al-Azemi MK, Omu AE, Fatinikun T, Mannazhath N, Abraham S. Factors contributing to gender differences in serum retinol and alpha-tocopherol in infertile couples. Reprod Biomed Online 2009; 19(4):583-90.

42. Safarinejad MR, Safarinejad S. Efficacy of selenium and/or $\mathrm{N}$-acetyl-cysteine for improving semen parameters in infertile men: a double-blind, placebo controlled, randomized study. J Urol 2009; 181(2):741-51.

43. Scott R, MacPherson A, Yates RW, Hussain B, Dixon J. The effect of oral selenium supplementation on human sperm motility. Br J Urol 1998; 82(1):76-80.

44. Paszkowski T, Traub Al, Robinson SY, McMaster D. Selenium dependent glutathione peroxidase activity in human follicular fluid. Clin Chim Acta 1995; 236(2):173-80.

45. Omu AE, Al-Azemi MK, Kehinde EO, Anim JT, Oriowo MA, Mathew TC. Indications of the mechanisms involved in improved sperm parameters by zinc therapy. Med Princ Pract 2008; 17(2):108-16.

46. Wong WY, Merkus HM, Thomas CM, Menkveld R, Zielhuis GA, Steegers-Theunissen RP. Effects of folic acid and 
zinc sulfate on male factor subfertility: a double-blind, randomized, placebo-controlled trial. Fertil Steril 2002; 77(3):491-8.

47. Mancini A, De Marinis L, Oradei A, Hallgass ME, Conte G, Pozza D et al. Coenzyme Q10 concentrations in normal and pathological human seminal fluid. J Androl 1994; 15(4):591-4.

48. Balercia G, Mancini A, Paggi F, Tiano L, Pontecorvi A, Boscaro $M$ et al. Coenzyme Q10 and male infertility. J Endocrinol Invest 2009; 32(7):626-32.

\section{UTICAJ ISHRANE NA FERTILITET KOD LJUDI}

Vesna Otašević ${ }^{1}$, Aleksandra Korać ${ }^{2}$ Ana Stančić ${ }^{\prime}$, Aleksandra Janković ${ }^{\prime}$ Bato Korać1,2

${ }^{1}$ Univerzitet u Beogradu, Institut za biološka istraživanja "Siniša Stanković", Bulevar despota Stefana 142, Beograd, Srbija;

2 Univerzitet u Beogradu, Biološki fakultet, Beograd, Srbija.

\section{Kratak sažetak}

Neplodnost je jedan od najtežih medicinskih problema koji je dramatično u porastu širom sveta. Obimna istraživanja posvećena ovom problemu jasno su pokazala da je neplodnost bolest modernog društva i da ishrana ima veliki uticaj na razvoj steriliteta. Iz tog razloga, uticaj specifičnih nutritivnih faktora, tj. specifičnih tipova ishrane je uvršćen u ovaj pregled. Ono što ohrabruje jeste činjenica da modifikacija načina ishrane može pomoći parovima da spontano ostvare trudnoću, ili da povećaju šanse za trudnoću in vitro fertilizacijom (IVF).

Ključne reči: Sterilitet, ishrana, gojaznost, masti, ugljeni hidrati, proteini, mikronutrijenti 